\title{
Surface structure and stability of the Larsen C ice shelf, Antarctic Peninsula
}

\author{
N.F. GLASSER, ${ }^{1}$ B. KULESSA, ${ }^{2}$ A. LUCKMAN, ${ }^{2}$ D. JANSEN, ${ }^{2}$ E.C. KING, ${ }^{3}$ \\ P.R. SAMMONDS, ${ }^{4}$ T.A. SCAMBOS, ${ }^{5}$ K.C. JEZEK ${ }^{6}$ \\ ${ }^{1}$ Centre for Glaciology, Institute of Geography and Earth Sciences, Aberystwyth University, Aberystwyth SY23 3DB, UK \\ E-mail:nfg@aber.ac.uk \\ ${ }^{2}$ School of the Environment and Society, Swansea University, Singleton Park, Swansea SA2 8PP, UK \\ ${ }^{3}$ British Antarctic Survey, Natural Environment Research Council, Madingley Road, Cambridge CB3 OET, UK \\ ${ }^{4}$ Department of Earth Sciences, University College London, Gower Street, London WC1E 6BT, UK \\ ${ }^{5}$ National Snow and Ice Data Center, CIRES, University of Colorado, Boulder, Colorado 80309-0449, USA \\ ${ }^{6}$ Byrd Polar Research Center, The Ohio State University, 1090 Carmack Road, Columbus, Ohio 43210-1002, USA
}

\begin{abstract}
A structural glaciological description and analysis of surface morphological features of the Larsen C ice shelf, Antarctic Peninsula, is derived from satellite images spanning the period 1963-2007. The data are evaluated in two time ranges: a comparison of a 1963 satellite image photomosaic with a modern digital mosaic compiled using 2003/04 austral summer data; and an image series since 2003 showing recent evolution of the shelf. We map the ice-shelf edge, rift swarms, crevasses and crevasse traces, and linear longitudinal structures (called 'flow stripes' or 'streak lines'). The latter are observed to be continuous over distances of up to $200 \mathrm{~km}$ from the grounding line to the ice-shelf edge, with little evidence of changes in pattern over that distance. Integrated velocity measurements along a flowline indicate that the shelf has been stable for $\sim 560$ years in the mid-shelf area. Linear longitudinal features may be grouped into 12 units, each related to one or a small group of outlet feeder glaciers to the shelf. We observe that the boundaries between these flow units often mark rift terminations. The boundary zones originate upstream at capes, islands or other suture areas between outlet glaciers. In agreement with previous work, our findings imply that rift terminations within such suture zones indicate that they contain anomalously soft ice. We thus suggest that suture zones within the Larsen $C$ ice shelf, and perhaps within ice shelves more generally, may act to stabilize them by reducing regional stress intensities and thus rates of rift lengthening.
\end{abstract}

\section{INTRODUCTION}

\section{Ice-shelf stability}

Ice shelves fringe more than $40 \%$ of the Antarctic continent (Drewry and others, 1982). In recent years, rapid changes have taken place in the extent of ice shelves in both the Arctic (Copland and others, 2007) and the Antarctic (Braun and others, 2008). Recent ice-shelf collapse events on the Antarctic Peninsula have been attributed to atmospheric or oceanic warming (Doake and Vaughan, 1991; Rott and others, 1998; Scambos and others, 2000; Shepherd and others, 2003), although structural glaciological factors are also recognized to be important (Glasser and Scambos, 2008). On the Antarctic Peninsula, it has been proposed that the limit for ice-shelf viability coincides with the $1.5^{\circ} \mathrm{C}$ January isotherm and the $-5^{\circ} \mathrm{C}$ mean annual isotherm, both of which have migrated south during the last 50 years (Rott and others, 1996, 1998; Vaughan and Doake, 1996). In this region, mean summer temperatures have risen to near-melting and the length of the melt season has doubled during the past two decades. Extensive meltwater ponds have appeared on the surface of many Antarctic Peninsula ice shelves during the melt season (Van den Broeke, 2005). It has been suggested that this meltwater acts as a mechanical force in crevasses, to cause breaks in the ice shelf and thus aid ice-shelf disintegration (MacAyeal and others, 2003; Scambos and others, 2003).
Remotely sensed glacier speed and elevation measurements have revealed that ice-shelf removal leads to the thinning and acceleration of tributary glaciers (Thomas and others, 1979; De Angelis and Skvarca, 2003; Rignot and others, 2004; Scambos and others, 2004; Pritchard and Vaughan, 2007).

\section{Ice-shelf surface features}

Descriptions exist of the surface features of selected Antarctic outlet glaciers and ice shelves (e.g. the FilchnerRonne Ice Shelf (Crabtree and Doake, 1980; Swithinbank and others, 1988), the George VI Ice Shelf (Reynolds and Hambrey, 1988), the Lambert Glacier-Amery Ice Shelf system (Hambrey and Dowdeswell, 1994), the former Larsen B ice shelf (Glasser and Scambos, 2008) and Byrd Glacier (Casassa and Brecher, 1993)). Skvarca (1994) described changes and surface features on the Larsen Ice Shelf using Kosmos Kate-200 images from 1975 and Landsat Thematic Mapper images from 1986-89. Bindschadler and others (2002) have described dolines on the surface of the Larsen B ice shelf, and Evans and Ó Cofaigh (2003) have described supraglacial debris along the front of the Larsen A ice shelf. However, very little is known about the temporal or spatial changes in the distribution of iceshelf surface features, their significance for ice-mechanical properties, ice dynamics and ice flow, or their potential as a tool for assessing ice-shelf stability. 


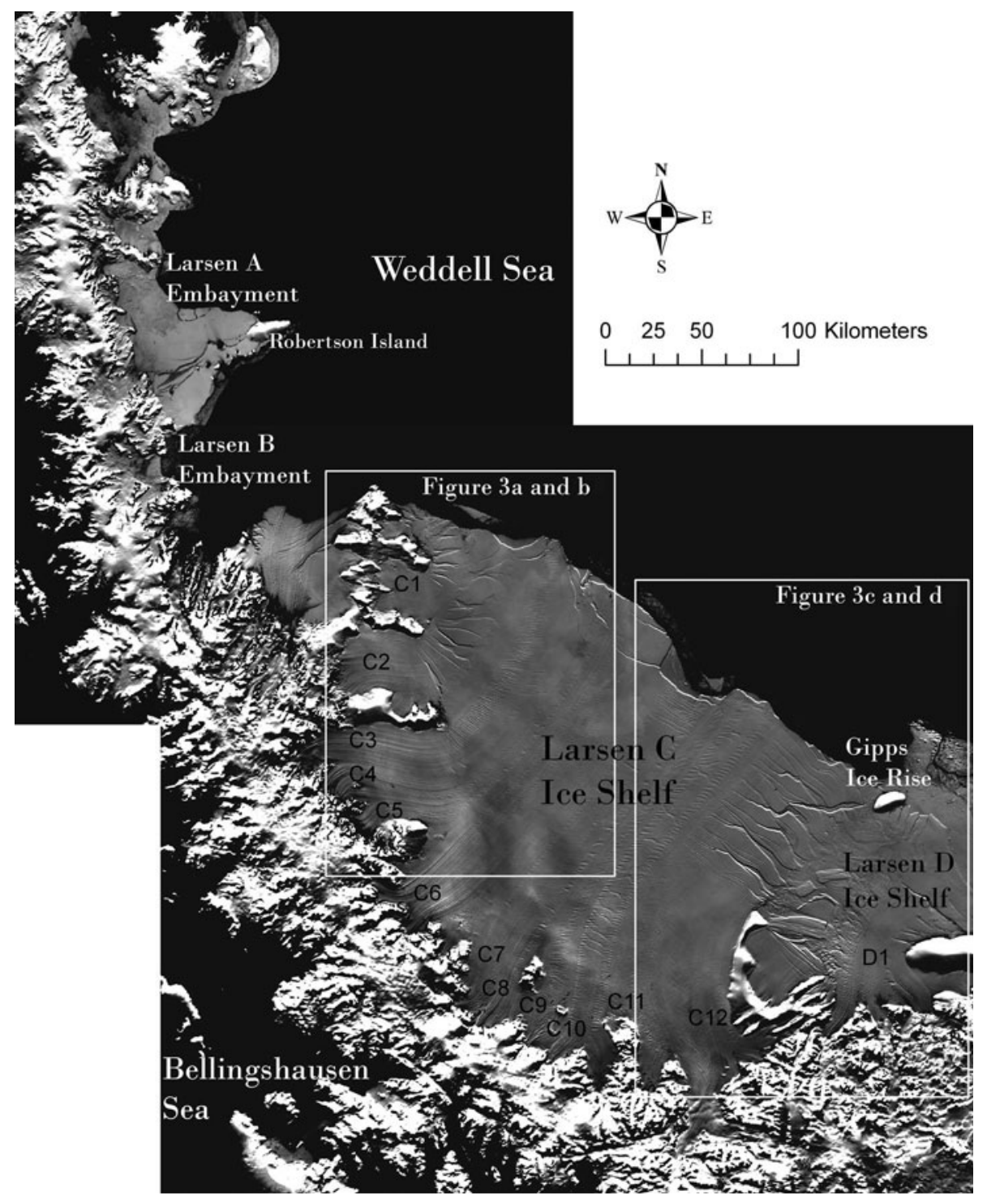

Fig. 1. The Larsen Ice Shelf system on the eastern side of the Antarctic Peninsula (MODIS image from the Mosaic of Antarctica (MOA) acquired between 20 November 2003 and 29 February 2004). Numbers C1-C12 on the Larsen C ice shelf and D1 on the Larsen D ice shelf indicate tributary-glacier domains discussed in the text.

\section{Ice-shelf mechanics}

Ice-surface features represent visual records of ice-shelf dynamic history and thus can reflect their structural and mechanical heterogeneity. Indeed, ice shelves are usually 'anything but a flat sheet of ice' (Bentley and others, 1979) because (a) meteoric ice is usually thicker down-flow of the grounding lines of ice streams and outlet glaciers, and thinner down-flow of mountain fronts separating individual ice-sheet outlets (Bentley and others, 1979; Bamber and Bentley, 1994); and (b) the spatial distribution of marine ice is usually non-uniform (Fricker and others, 2001; Joughin and Vaughan, 2004) because of complex interactions between ocean and ice-shelf base in the sub-ice-shelf cavity (Bombosch and Jenkins, 1995). Marine ice can reach thicknesses of several hundred metres and therefore constitute a considerable percentage of the total ice-shelf thickness (Engelhardt and Determann, 1987).

As a consequence of this structural complexity, Antarctic ice shelves are commonly composed of three mechanically distinct ice types: (a) meteoric ice derived from the interior of the Antarctic ice sheet which is relatively cold and stiff; (b) relatively soft meteoric ice with previously or currently modified temperature, density or ice fabrics; and (c) marine ice with modified temperature and salt content which is also soft relative to category (a). Potential origins for the relatively soft ice in category (b) include (1) the shear margins of ice shelves, which are often softened as a consequence of enhanced friction (Rommelaere and MacAyeal, 1997; Larour and others, 2005; Vieli and others, 2006) and (2) ice derived down-flow of mountain fronts at the grounding line, which is typically anomalously thin and subject to elevated extensional strain (Bentley and others, 1979; Bamber and Bentley, 1994; Fahnestock and others, 2000). Significantly for the present study, the principles of icefracture mechanics (Van der Veen, 1998; Rist and others, 1999; Larour and others, 2004) imply that softer meteoric or marine ice is more resistant to fracture than stiffer meteoric ice as a result of regionally reduced stress intensity. Surprisingly little is currently known about the internal structure and dynamic behaviour of the Larsen $\mathrm{C}$ ice shelf or the oceanographic processes beneath it (Nicholls and others, 2004). 
Table 1. Mapped structural glaciological features, with identification criteria and significance

\begin{tabular}{|c|c|c|}
\hline Feature & Identification on satellite imagery & Significance \\
\hline Ice-shelf edge & $\begin{array}{l}\text { Abrupt transition from ice shelf to ocean. Calved } \\
\text { icebergs often visible in ocean in front of the ice shelf. }\end{array}$ & $\begin{array}{l}\text { Indicates maximum extent of the ice shelf. Time series can } \\
\text { be used to trace advance or recession of ice-shelf extent } \\
\text { through time. }\end{array}$ \\
\hline Rifts & $\begin{array}{l}\text { Surface crack with a visible opening, usually oriented } \\
\text { at right angles to the flow direction and deep enough } \\
\text { to penetrate the entire shelf thickness. }\end{array}$ & $\begin{array}{l}\text { Rifts are formed when the stresses within the ice exceed the } \\
\text { fracture toughness of the ice. Formed perpendicular to the } \\
\text { direction of maximum tension. }\end{array}$ \\
\hline $\begin{array}{l}\text { Crevasses and crevasse } \\
\text { fields }\end{array}$ & $\begin{array}{l}\text { Surface cracks appearing either as white lines (snow- } \\
\text { filled) or dark lines (non-snow-filled or water-filled), } \\
\text { which cross-cut other features. Varied orientation with } \\
\text { respect to ice flow. }\end{array}$ & $\begin{array}{l}\text { Crevasses are formed when the stresses within the ice } \\
\text { exceed the fracture toughness of the ice. Formed per- } \\
\text { pendicular to the direction of maximum tension. Open } \\
\text { crevasses may indicate locations of extensional flow. }\end{array}$ \\
\hline $\begin{array}{l}\text { Longitudinal surface } \\
\text { structures (also known as } \\
\text { flow stripes, flow bands, } \\
\text { flowlines, streak lines or } \\
\text { foliation) }\end{array}$ & $\begin{array}{l}\text { Long linear pervasive layered structure parallel to ice } \\
\text { movement. Horizontal dimensions of } 1 \mathrm{~km} \text { or less but } \\
\text { can extend for many tens or even hundreds of } \\
\text { kilometers. Often generated in regions of positive relief, } \\
\text { at bed protuberances or in regions of increased basal } \\
\text { friction. Often seen to emanate from the confluences } \\
\text { of separate ice streams or glaciers. }\end{array}$ & $\begin{array}{l}\text { Provides visual impression of the ice-motion direction. } \\
\text { Cumulative length is due to slow decay timescale relative to } \\
\text { the time required for ice to travel a long distance. }\end{array}$ \\
\hline Flow unit boundary & $\begin{array}{l}\text { Structural discontinuity or junction that separates } \\
\text { structures rotated in one orientation from structures } \\
\text { rotated in a different orientation. Structures may be } \\
\text { 'smeared' along the junction. }\end{array}$ & Indicates confluence of individual flow units or glaciers. \\
\hline
\end{tabular}

\section{Aims of this study}

In this paper, we present the results of detailed structural glaciological mapping of the Larsen $\mathrm{C}$ ice shelf over two timescales. First, we present information concerning changes in the entire Larsen ice-shelf system (Larsen A, B, C and D) over a 40 year period between 1963 and 2003/ 04. Second, we provide details of changes on the surface of the Larsen C ice shelf between 2002 and 2007. We then use these structural glaciological observations to make inferences concerning ice-mechanical heterogeneity, icedynamical and ice-flow regimes, and to comment on potential ice-shelf stability.

\section{FIELD AREA AND METHODS}

\section{Field area}

Following the terminology of Vaughan and Doake (1996), the Larsen ice-shelf system comprises four major ice shelves (Larsen A, B and C are shown in Figure 1; the Larsen D shelf is much smaller and extends south of Gipps Ice Rise (Fig. 1)) and their tributary glaciers. Of the northern three ice shelves, only the southwest corner of Larsen B and Larsen C are still in existence. Larsen A receded and then collapsed in January 1995, with the loss of $1600 \mathrm{~km}^{2}$ of ice shelf (Skvarca, 1993; Rott and others, 1996). Larsen B partially collapsed in February-March 2002, with the loss of $3250 \mathrm{~km}^{2}$ of ice shelf (Scambos and others, 2003; Rack and Rott, 2004).

\section{Methods}

Surface structures on the Larsen Ice Shelf area and its tributary glaciers were mapped from satellite imagery in ArcMap Geographical Information System (GIS) software using time-separated images. We used two different sensors to map the features. To examine long-term changes in the extent and structure of the entire ice-shelf complex (Larsen A, B, C and D) we used the earliest images of this area, the
US Department of Defense declassified intelligence satellite photography (DISP) images acquired in 1963 (Bindschadler and Seider, 1998; Bindschadler and Vornberger, 1998; Kim and others, 2007), and compared these to the moderateresolution imaging spectroradiometer (MODIS) Mosaic of Antarctica (MOA) image map, a composite of 260 swaths comprised of both Terra and Aqua MODIS images acquired between 20 November 2003 and 29 February 2004 (Scambos and others, 2007).

MOA provides a cloud-free view of the Antarctic ice sheet, ice shelves and land surfaces at a gridscale of $125 \mathrm{~m}$ and an estimated resolution of $150 \mathrm{~m}$. Images were destriped, geo-referenced, and resampled using the MODIS Swath-to-Grid Tool (MS2GT) software available at the US National Snow and Ice Data Center (NSIDC). Acquisition times for MOA were limited to 0500-1300 Universal Time (with few exceptions) to provide a more uniform illumination direction across the mosaic (Scambos and others, 2007). To examine short-term changes we also used three individual MODIS channel 2 images of the Larsen $C$ ice shelf acquired on 17 March 2002, 2 February 2003 and 8 March 2007. Standard image-enhancement procedures (contrast stretching and histogram equalization) were used to improve the contrast and signal strength of the individual MODIS channel 2 images.

In all cases, mapped features include the location of the ice-shelf edge, the location of rifts (open fractures where it is clear on optical satellite images that the fracture penetrates to some depth within the ice shelf), crevasses and crevasse traces (the down-ice expression of healed crevasses) and linear longitudinal surface structures, also called flow stripes, flowlines, flow traces or streak lines (Crabtree and Doake, 1980; Reynolds and Hambrey, 1988; Swithinbank and others, 1988; Casassa and Brecher, 1993; Merry and Whillans, 1993; Fahnestock and others, 2000). Meltwater features (e.g. streams and ponds), although recognized as important components of the ice-shelf 
a

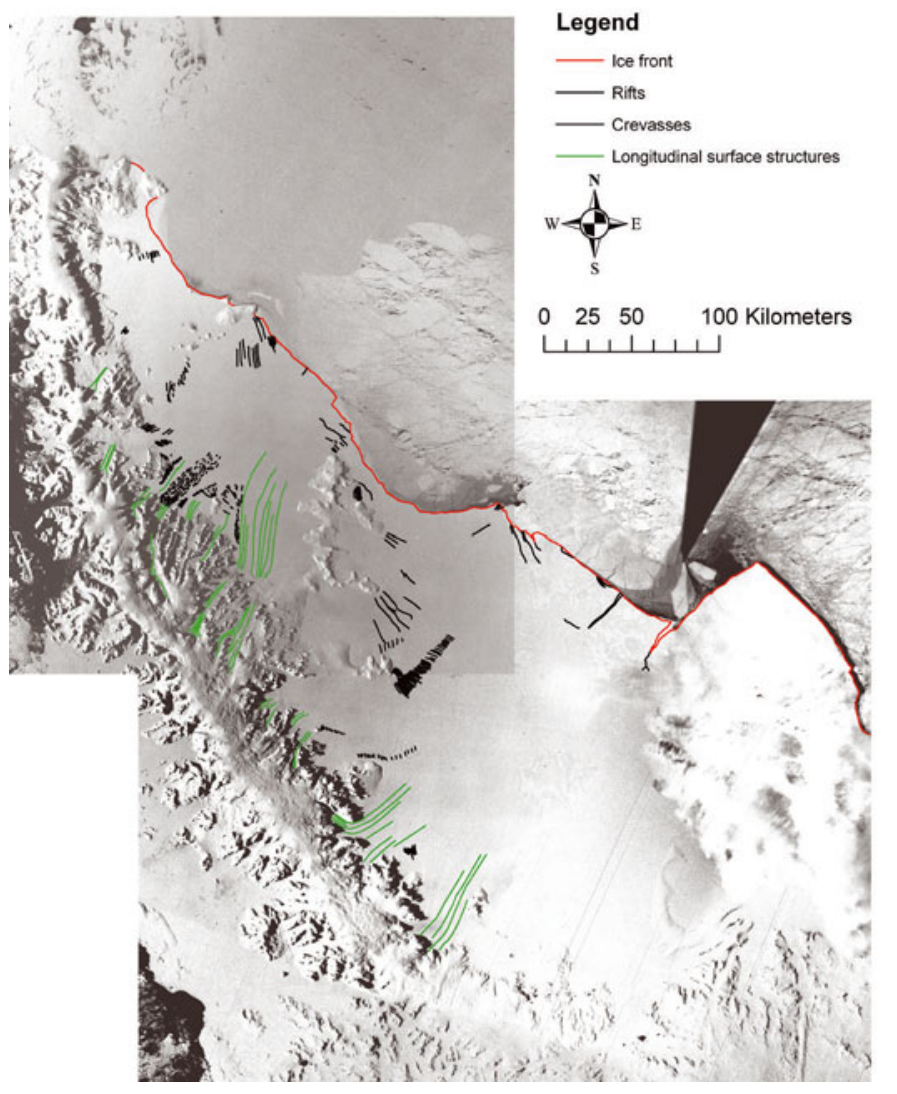

b

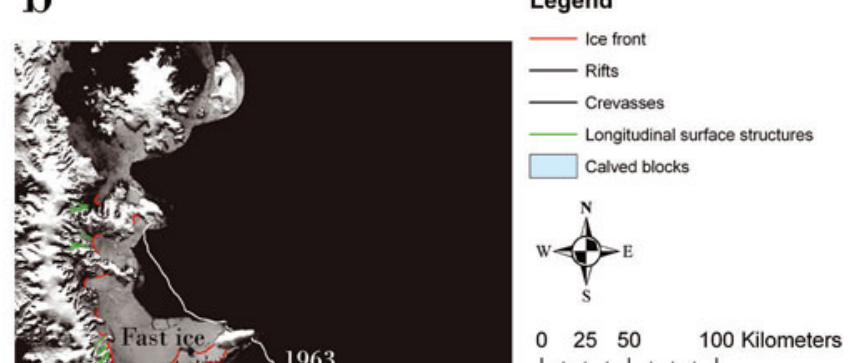

Fig. 2. Structural glaciological interpretations of the ice shelves on the eastern side of the Antarctic Peninsula in 1963 and 2003/04. (a) The Larsen A, B and C ice shelves interpreted from US Department of Defense DISP images acquired in 1963. (b) The Larsen C ice shelf and remnant Larsen B ice shelf interpreted from the 2003/04 MODIS image from the MOA. The position of the 1963 ice-shelf front has been added for comparison.

system, were not mapped in this study because these features typically have dimensions less than the estimated resolution $(150 \mathrm{~m})$ of the MODIS images. A list of all mapped features, with their identification criteria and significance, is provided in Table 1.

In support of our ice-mechanical inferences we also compare digitized MOA and IfAG (Institute for Applied Geodesy, Germany) Landsat mosaic data, collected between 1986 and 1990 over the southeastern portion of the Larsen C ice shelf. This allowed tracking of the displacement of rift tips in this sector.

\section{RESULTS}

\section{Comparison of 1963 DISP and 2003/04 MODIS MOA datasets}

Taken together, the 1963 DISP image (Fig. 2a) and the 2003/04 MODIS MOA images (Fig. 2b) provide a 40 year record of changes in ice-shelf extent and structures. Information is limited by the quality of the 1963 DISP image, but large-scale structures such as rifts, crevasses and longitudinal surface structures are visible on the surfaces of the Larsen A, B, C and D ice shelves (Fig. 2a). The 1963 position of the front of the now-collapsed Larsen A ice shelf, the partially collapsed Larsen B ice shelf and the extant Larsen $\mathrm{C}$ and $\mathrm{D}$ ice shelves can be defined clearly over a distance of $\sim 500 \mathrm{~km}$. Longitudinal surface structures visible on the surface of Larsen B and C ice shelves clearly originate in the tributary glaciers flowing into the shelf from the Antarctic Peninsula.

The 2003/04 MODIS MOA image covers only the surface of the Larsen C and D ice shelves (Larsen A ice shelf collapsed in January 1995 and Larsen B ice shelf partially collapsed in February-March 2002). Longitudinal surface structures dominate the ice shelf (Fig. 2b). In some places, these structures can be traced from their origin in the tributary glaciers of the Antarctic Peninsula as far as the shelf edge. In other places, the longitudinal surface structures are truncated abruptly by rifts or crevasses and crevasse traces (Fig. 3a and b). The combination of crevasse and crevasse-trace patterns and longitudinal surface structures can be used to define individual flow units, some of which can be traced over distances of up to $\sim 200 \mathrm{~km}$ from the tributary glaciers on the Antarctic Peninsula to the shelf edge (Fig. 1).

Twelve major flow units (ice-shelf domains) are visible on the Larsen C ice shelf (Fig. 1), marked by the longitudinal surface structures originating in the trunks of individual tributary glacier flow units. Because the longitudinal surface structures can be traced uninterrupted all the way to the shelf edge (e.g. domains C4, C5, C8, C10 and C11; Fig. 1), we infer that these glaciers are fast-flowing and actively contribute mass to the ice shelf. Between the active domains are a number of domains without longitudinal surface structures and lacking significant up-glacier catchments (e.g. 


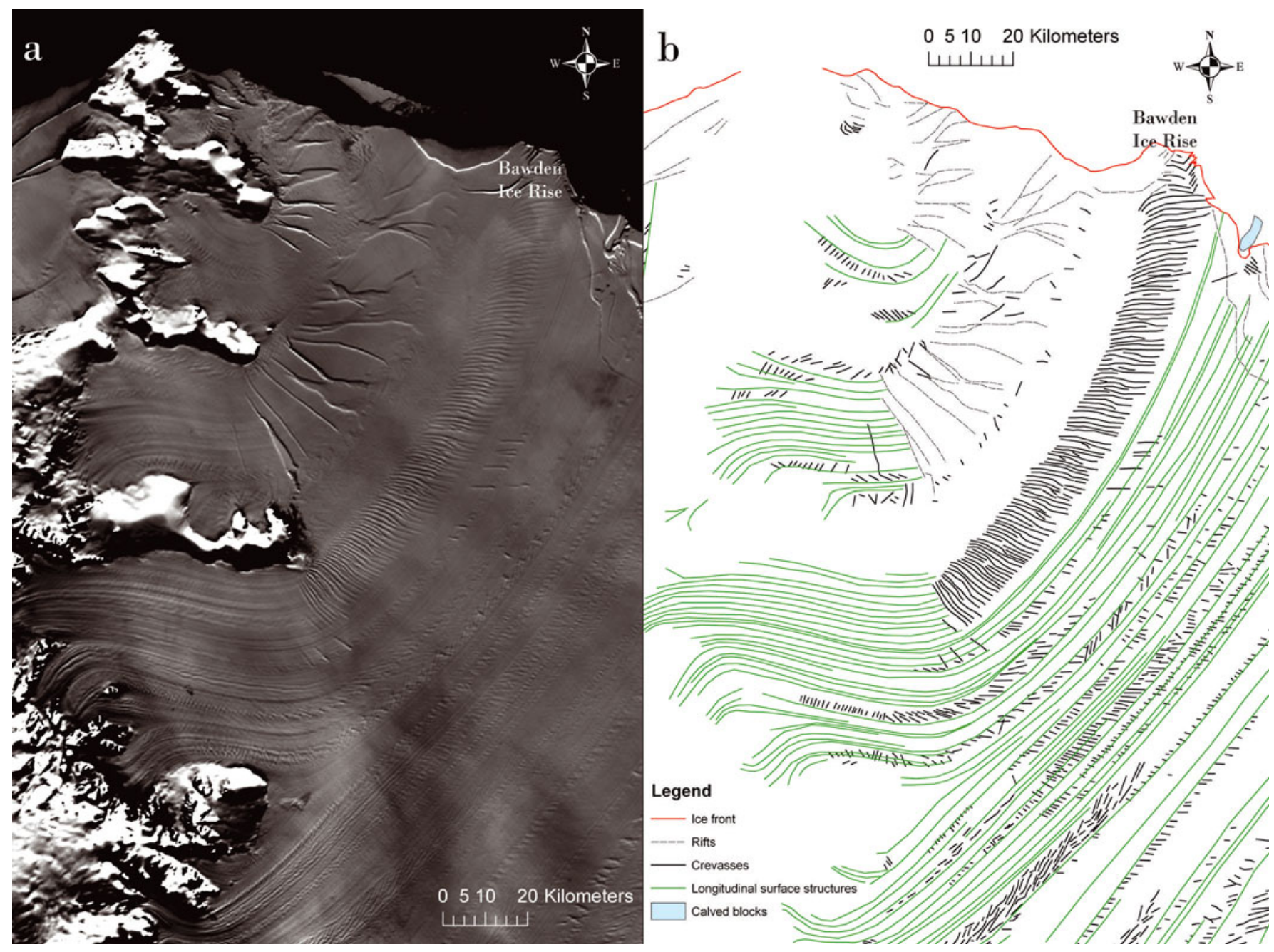

Fig. 3. Detail of 2003/04 MODIS image from the MOA (a, c) and interpreted structures $(b, d)$ on Larsen $C$ ice shelf. The locations of the panels are marked in Figure 1. $(a, b)$ Longitudinal surface structures terminating abruptly at the point on the shelf where rifts (upper part of image) and crevasses (lower part of image) first appear. Note how the zone of crevasses is confined laterally and does not widen down-shelf. (c, d) A rift system behind the Gipps Ice Rise near the 2003/04 ice-shelf edge. Large calved blocks are 'floating' within the rift system up to $90 \mathrm{~km}$ from the ice-shelf edge.

the areas between domains $\mathrm{C} 5$ and $\mathrm{C} 6$, between domains C6 and C7, and between domains C12 and D1 on Larsen D ice shelf).

Crevassed zones are restricted laterally and do not widen or spread laterally down-shelf (e.g. domain C3 in Fig. 1; Fig. 3a and b). Individual crevasse sets rarely cross longitudinal surface structure boundaries, suggesting that the longitudinal surface structures separate individual flow units or domains (e.g. domains C10 and C11 in Fig. 1; Fig. 3c and d). Longitudinal surface structures cannot be traced to the shelf edge where heavy crevassing is initiated (e.g. domains C2 and C12; Fig. 1). Two types of rift system are present. Type 1 rifts ('ice-shelf edge rifts') are common near the shelf edge (e.g. at the shelf edge of domain C7 (Fig. 1) and at the shelf edge of domain C12). These rifts typically form in sets parallel to the shelf edge. Type 2 rifts ('tributary-glacier rift systems') are developed in the less active zones between the active coalescing tributary glaciers (Fig. $3 \mathrm{c}$ and d), although they are also present further up-ice on the Larsen $\mathrm{C}$ ice shelf, for example where they are developed between nunataks (domains C2 and D1 in Fig. 1; Fig. 3c and d). In places, the rift zones contain calved blocks and brash ice, which appear to be 'floating' in open water within the rifts (Fig. 3c and d).
Tributary-glacier rift systems containing calved blocks are visible at some distance (up to $90 \mathrm{~km}$ ) from the position of the 2003/04 ice-shelf edge.

\section{Changes in the Larsen C ice shelf between 2002 and 2007 from MODIS}

We used MODIS channel 2 (near-infrared) images acquired on 17 March 2002 (Fig. 4a), 2 February 2003 (Fig. 4b) and 8 March 2007 (Fig. 4c) to investigate short-term changes in the structure of the Larsen $\mathrm{C}$ ice shelf and to assess its potential future instability. These images show that the gross structures in the ice shelf changed little in the 5 years between March 2002 and March 2007. Contributions to the ice shelf from the individual tributary glaciers and the locations of major crevasses and rifts all appear to be relatively constant. Indeed, many of the mapped features are visible on the map presented by Skvarca (1994, his fig. 3) compiled from 1989 Landsat images, suggesting there has been little change in the overall structure of the ice shelf in the last two decades. There has been a gradual recession of the ice-shelf edge, as well as the loss of a large area of ice shelf (measuring $\sim 26.5 \mathrm{~km} \times 56.7 \mathrm{~km}$ ) in the zone marked 'Area 1' in Figure 4. Feature tracking 


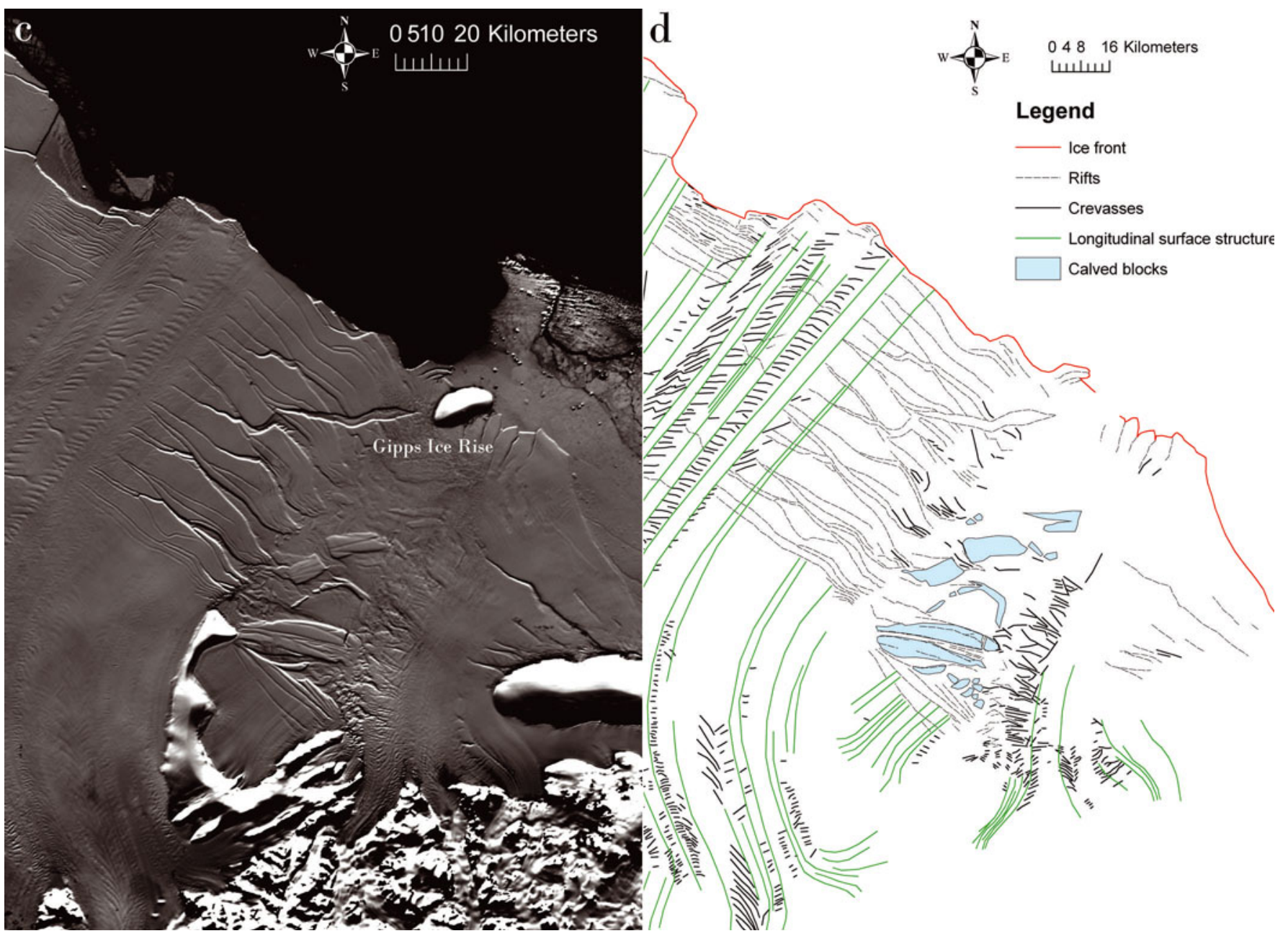

Fig. 3. continued.

(measurements of feature displacement) of rifts near the iceshelf edge in the vicinity of the zone marked 'Area 2' in Figure 4 indicates a mean total displacement of $3.2 \mathrm{~km}$ (mean of ten separate measurements). This is equivalent to a mean velocity of $\sim 640 \mathrm{~m} \mathrm{a}^{-1}$ between 2002 and 2007 . This mean velocity is similar to, but slightly higher than, those derived by Skvarca (1994) who estimated velocities of $\sim 430$ to $\sim 550 \mathrm{~m} \mathrm{a}^{-1}$ between 1975 and 1986 near the front of the ice shelf.

\section{Ice-mechanical heterogeneity and associated rifting}

Most notably, there are many instances where the tips of parallel or near-parallel rifts (e.g. domain C12; Fig. 1) align along narrow ice-flow domains that originate down-flow of mountain fronts (e.g. domain C11; Fig. 1). The most prominent of these occurs in the southeastern sector of the ice shelf (Fig. 3c). Tracking of rift-tip displacement between 1986-90 and 2003 reveals that this series of subparallel rifts has advected approximately $10 \mathrm{~km}$ along with ice flow (Fig. 5). The distance advected is consistent along the entire rift series, and direction of advection is aligned parallel to domain C11 (Figs 1 and 5). No significant rift lengthening has occurred during this period. Comparison of the 1986-90 and 2003 mosaics reveals, further, that several new rifts formed at the upstream end of the rift series. The tips of all of these new rifts also align along domain C11 (Figs 3c and 5).

\section{INTERPRETATION OF STRUCTURES AND THEIR SIGNIFICANCE FOR ICE-SHELF DYNAMICS AND POTENTIAL STABILITY}

\section{Longitudinal surface structures}

The dominant flow-related features on the surface of the Larsen $\mathrm{C}$ ice shelf are longitudinal surface structures (Figs 1 and $4 a-c)$. On ice shelves and glaciers where a threedimensional relationship can be demonstrated, these longitudinal surface structures have been termed foliation (Hambrey and Dowdeswell, 1994; Hambrey and Glasser, 2003). On the Larsen $C$ ice shelf, they appear to develop in two situations: (1) where they are inherited from ice flow in the ice-shelf tributary glaciers, and (2) where they develop parallel to the margins of individual flow units.

Two striking attributes of these features are their persistence down-ice and that they do not appear to spread laterally down-ice. It is not clear how these longitudinal surface structures develop or how they maintain their presence down-ice. On small valley glaciers with multiple basins feeding a narrow tongue, longitudinal foliation develops in response to lateral compression and it appears that this situation also applies to the Antarctic Peninsula glaciers in this study. In this case, longitudinal surface structures are created by the visco-plastic deformation of pre-existing inhomogeneities, i.e. primary stratification, under laterally compressive and longitudinally tensile 


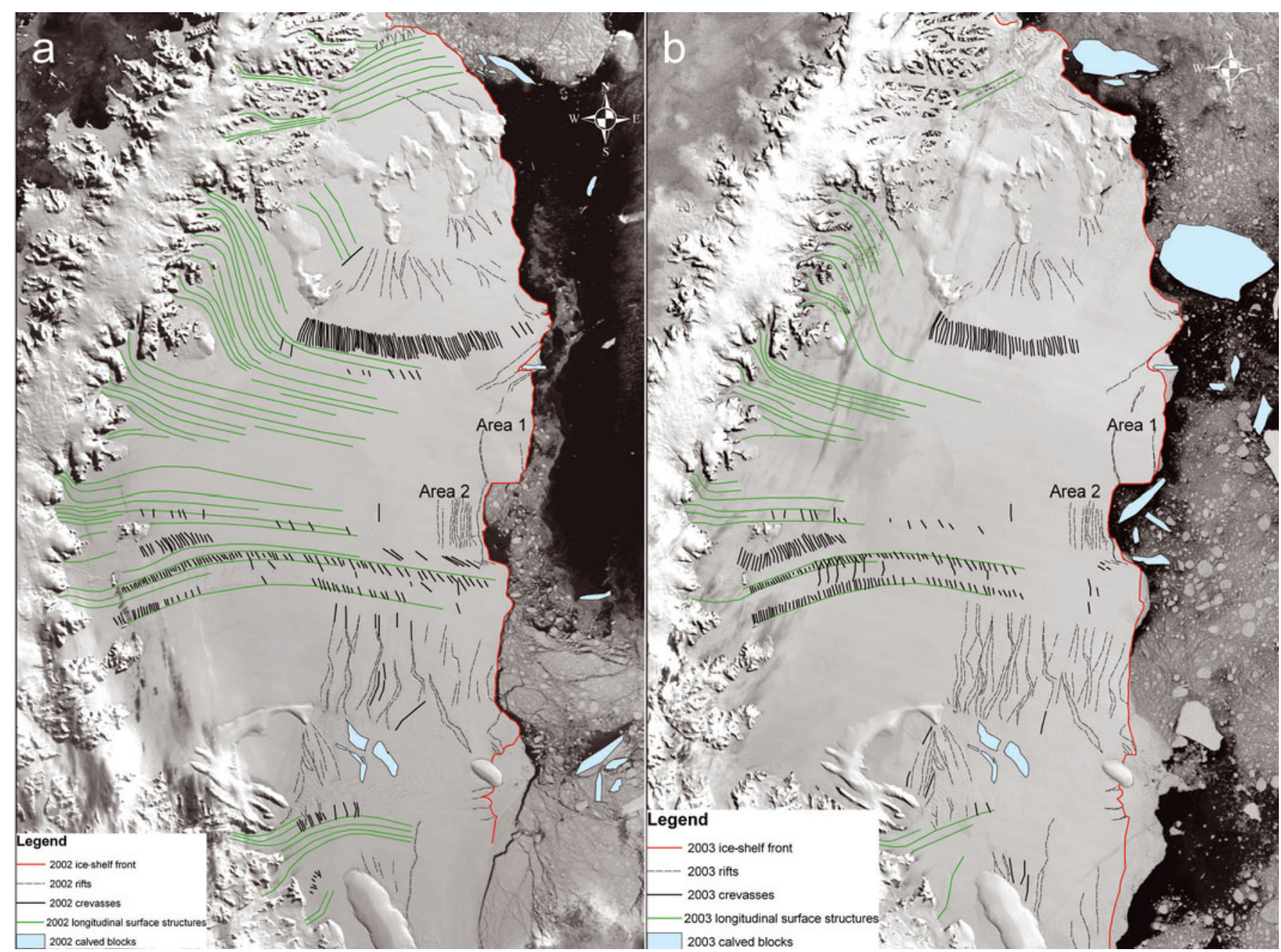

Fig. 4. Changes in surface structures on the Larsen C ice shelf superimposed on MODIS channel 2 images acquired between 2002 and 2007. (a) Interpretation based on 17 March 2002 image. (b) Interpretation based on 2 February 2003 image. (c) Interpretation based on 8 March 2007 image. Areas marked 1 and 2 refer to areas discussed in the text.

stresses (Hambrey, 1977; Hooke and Hudleston, 1978). Another plausible explanation for these features is that they develop parallel to the margins of individual flow units, with the longitudinal structures representing 'shear zones' between individual flow units, although we note that Casassa and Brecher (1993), working on Byrd Glacier, found no velocity discontinuities across the boundaries between individual flow stripes. Whatever their precise origin, we infer that where these features are present, tributary glaciers are fast-flowing or active and that where they are absent, tributary glaciers are less active.

\section{Crevasses and crevasse traces}

Crevasses open because of glacier and ice-shelf deformation during horizontal motion and in extensional regimes where the stresses acting on suitably oriented pre-existing cracks exceed some threshold (Vaughan, 1993; Rist and others, 2002; Larour and others, 2004). Crevasse traces are the down-ice expression of healed crevasses. On ice shelves, crevasses and crevasse traces are important because they indicate the dynamic activity of different flow units entering the ice shelf. In some cases (e.g. in domains C9, C10 and C11; Fig. 1), crevasses are initiated in the tributary glaciers and can be traced from here to the ice-shelf front. In other cases (e.g. in domain C3; Fig. 1, enlarged in Fig. 3a and b), crevasses are initiated at some distance along a flow unit in the vicinity of inferred subglacial topographic obstacles, in this case at the Bawden Ice Rise. In both cases, individual crevasse sets do not cross longitudinal surface structure boundaries, and crevassed zones are restricted laterally. Crevasse sets do not widen or spread laterally down-shelf, indicating that the surrounding shelf ice is sufficiently strong to resist crevassing.

\section{Ice-shelf edge rifts (type 1 rifts)}

Type 1 rifts develop only close to the ice-shelf edge (Fig. 3c and d). They open and propagate as the ice shelf flexes due to tidal motion, because of ice-shelf deformation during horizontal motion, and in response to large calving events (Rist and others, 2002; Larour and others, 2004). For example, the large rifts near the front of domain $\mathrm{C} 12$ opened in response to a large calving event from this area of the ice shelf in 1986 (Skvarca, 1994). Dupont and Alley (2005) suggested that the presence of an ice shelf provides 'back-stress' or longitudinal compressive force and therefore inhibits motion behind the shelf. When this longitudinal compressive force is removed (e.g. after a large calving event), the ice shelf behind is free to accelerate and rifts will open. Rifts are important because their spacing strongly influences the dimensions of individual icebergs, as well as the frequency and magnitude of iceberg 


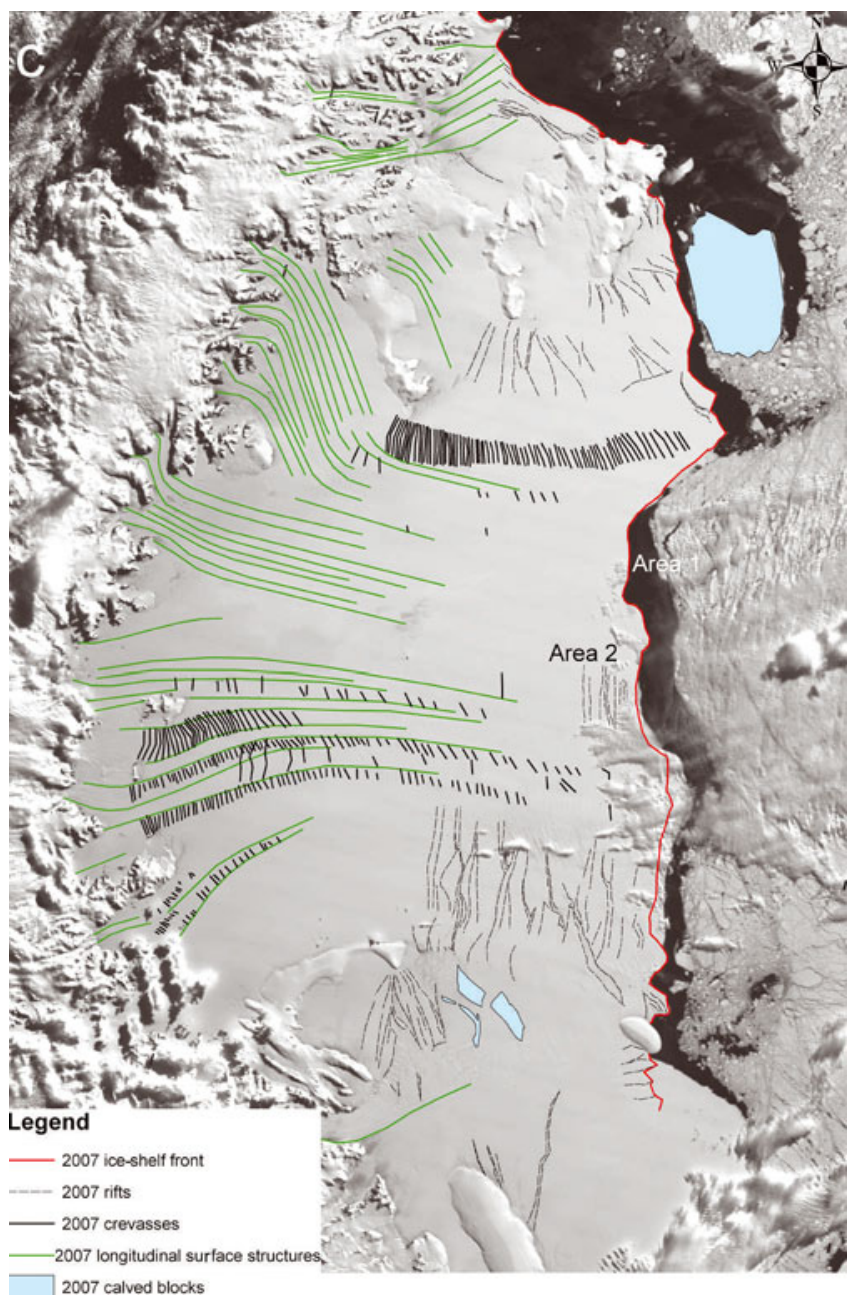

Fig. 4. continued.

calving events (Weiss, 2004; Joughin and MacAyeal, 2005). The control exerted by the location of ice-shelf edge rifts on iceberg calving is demonstrated by the changes visible at the front of the Larsen C ice shelf between 2002 and 2007 (area 2 in Fig. 4).

\section{Tributary-glacier rift systems and calved blocks (type} 2 rifts)

The second type of rift occurs in the less active zones between active coalescing tributary glaciers (Fig. 3c and d). On other Antarctic ice shelves, rift systems such as these have been observed to form in extensional flow regimes (Bassis and others, 2005, 2008; Fricker and others, 2005). We suggest that the Larsen $C$ rifts occur in these locations because of the strong lateral shear imparted on the less active zones between flow units by the more active flow units. Because open water containing calved blocks and brash ice is visible within the rifts, we also infer that the ice shelf is relatively thin in these areas. 'Calved' icebergs, brash ice, surface meltwater, blown snow and marine water are reincorporated into the shelf within the rifts and advected down-ice (cf. Jezek and Liu, 2005).

\section{Ice-shelf mechanical heterogeneity}

Prominent instances of rift-tip alignment along an ice-flow domain in the southeastern sector of the Larsen $C$ ice shelf (domain C11; Fig. 3c), and indeed elsewhere (Fig. 6), highlight the connection between such inferred suture zones

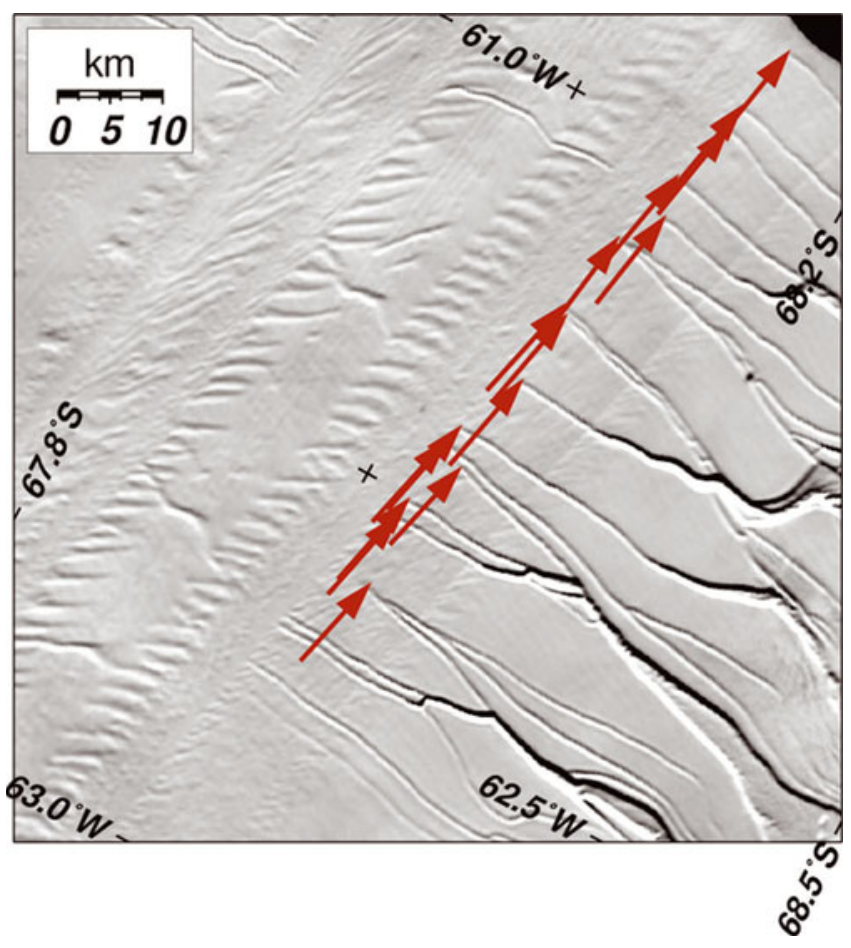

Fig. 5. Motion of ice-shelf rift tips between 1986-90 and 2003 and distance travelled as indicated by arrow directions and lengths (for location see box in Fig. 6).

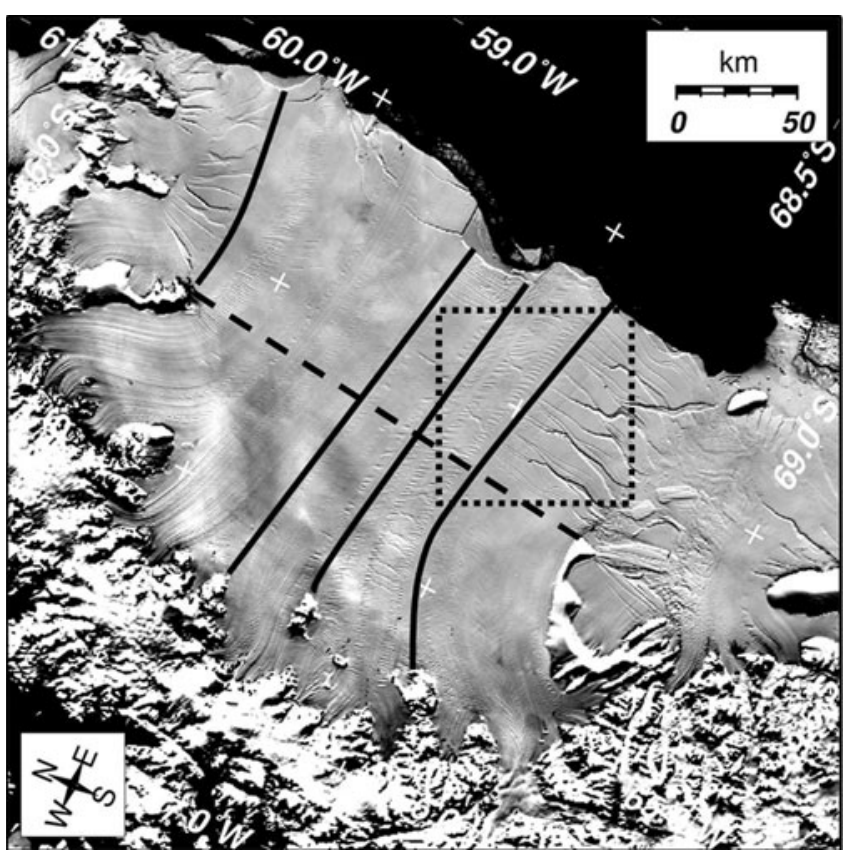

Fig. 6. MODIS MOA image of the Larsen $\mathrm{C}$ ice shelf. The northsouth dashed line indicates the approximate boundary between inferred compressive flow to the west and extensional flow to the east. The solid lines mark flow units of inferred softer meteoric ice responsible for rift-tip alignment downstream. The southernmost solid line is equivalent to domain $\mathrm{C} 11$ in Figure 1. The dotted box marks the location of Figure 5. 
and rifting. Indeed, alignments of rift tips similar to those observed here also occur on other Antarctic ice shelves, which led previous authors to hypothesize that the bounding ice-flow domains (e.g. domain C11; Fig. 3c) could be 'composed of softer ice that does not allow for crack propagation' (Fahnestock and others, 2000), with potentially significant implications for ice-shelf stability (Casassa and Whillans, 1994; Larour and others, 2005). Based on satellite observations, Fricker and others (2002) found that rifts can also form parallel to suture zones, and Bassis and others (2007) observed that a transverse rift slowed down and arrested once it entered such a zone. These authors hypothesized that this rift may have terminated at the suture zone because of the presence of smaller micro-cracks that diffuse the stress.

Preliminary analysis of ground-penetrating radar data collected in the 2008/09 austral summer along survey profiles aligned orthogonal and parallel to ice-flow domain C11 (Fig. 3c) on the Larsen C ice shelf (B. Kulessa, unpublished data) indicates that this mountain-front derived ice domain is structurally highly anomalous compared to the glacier-derived ice-flow domains to the south and north of it. Consistently, the geophysical data of Bentley and others (1979) also reflected structurally anomalous ice down-flow of a mountain front on the Ross Ice Shelf. We find that in all other prominent cases on the Larsen $\mathrm{C}$ ice shelf, rift-tip alignment occurs along mountain-front derived ice-flow units (for illustration, three additional instances are marked in Figure 6). In agreement with previous work, we thus conclude that ice-mechanical heterogeneity, governed principally by softer ice derived down-flow of mountain fronts, controls rates of rift propagation on the Larsen $\mathrm{C}$ ice shelf.

\section{Ice-shelf dynamics and potential ice-shelf stability}

Interpretation of the MODIS MOA images indicates that the Larsen $C$ ice shelf consists of 12 major flow units (domains) sutured along flow-unit boundaries (Fig. 1). Between these active flow units are less active flow units. There are no clear indications of previous ice-flow instabilities or past variations in ice-shelf configuration, as recorded by the deformation and rotation of flow-related features on the Ross Ice Shelf, which is fed primarily by ice streams (Fahnestock and others, 2000). The sutured flow units on the Larsen $\mathrm{C}$ ice shelf indicate that the ice shelf has existed in its present configuration for some time and there are no obvious signs (e.g. deformed or folded surface structures) that any of the Larsen $C$ tributary glaciers have surged in the past.

On the assumption that there has been minimal flow reorganization in the recent past, we can estimate residence times for the ice in the Larsen $C$ ice shelf by examining the surface velocity field along a typical flowline. To do this, we combined a number of sources of surface velocity data including the RADARSAT-1 Antarctic Mapping Project (RAMP; Jezek, 2002), and feature tracking between MODIS images and Landsat images to provide complete velocity coverage along a central flowline. By integrating these velocities from the grounding line to the calving front, we estimate the residence time of ice (ignoring basal melt and surface accumulation) to be $\sim 560$ years. We therefore suggest that the Larsen $C$ ice shelf has existed in its present configuration for at least this length of time. Independent support for this assertion comes from the sedimentary record on the adjacent continental shelf, which indicates that the more northerly Larsen B ice shelf was present throughout the Holocene until its 2002 demise (Domack and others, 2005).

Large, open-rift systems containing calved blocks are present $\sim 90 \mathrm{~km}$ from the ice-shelf edge around inland capes in the zone between the active and less active flow units in the northern part of the Larsen C ice shelf. Glasser and Scambos (2008) identified similar rift systems near capes on pre-collapse images of the former Larsen B ice shelf and cited these as evidence that the Larsen B ice shelf was thinning in the years prior to its final collapse. Although these rift zones identified here in the northern part of the Larsen C ice shelf could potentially represent mechanically weak areas within the ice shelf, we have not identified any major changes in the geometry, spatial distribution or size of the rifts between 2002 and 2007. Based on the distribution of the ice-shelf structures and their change over time and notwithstanding dramatic oceanic or atmospheric changes in the region or major variations in the flow regime of its contributing glaciers, we consider the prospect of an imminent collapse of Larsen $C$ ice shelf to be unlikely. Future changes in the ice shelf are likely to be dominated by gradual recession and thinning (Shepherd and others, 2003), as proposed for the George VI Ice Shelf on the west coast of the Antarctic Peninsula (Smith and others, 2007).

\section{CONCLUSIONS}

Important structural features of the Larsen C ice shelf include longitudinal surface structures, rifts, crevasses and crevasse traces. Longitudinal surface structures are particularly important because they can be used to define individual tributary-glacier flow units (domains) and their contribution to the ice shelf.

Comparison of DISP images acquired in 1963 and the MODIS MOA image from 2003/04 indicates that there have been few changes in the overall surface structure of the Larsen C ice shelf in this 40 year time window. Over shorter timescales, analysis of MODIS channel 2 images indicates that there were few changes in the surface structure of the Larsen C ice shelf between 2002 and 2007.

The Larsen C ice shelf consists of 12 major flow units (domains) sutured along flow-unit boundaries. Between these glacier-fed active flow units are less active flow units. Large, open-rift systems containing calved blocks are present $\sim 90 \mathrm{~km}$ from the ice-shelf edge in the zone between the active and less active flow units. These rift zones may represent potentially weak areas within the ice shelf and so warrant careful future monitoring.

Surface velocity data integrated from the grounding line to the calving front along a central flowline of the ice shelf indicate that the residence time of ice (ignoring basal melt and surface accumulation) is $\sim 560$ years. Based on the distribution of ice-shelf structures and their change over time, we infer that the ice shelf is likely to be a relatively stable feature and that it has existed in its present configuration for at least this length of time.

The presence of flow units containing anomalously soft meteoric ice limits rates of rift propagation and thus contributes to the stability of this ice shelf. We recommend therefore that mechanical heterogeneity be taken into account in models of climatically forced ice-shelf stability. Indeed, this may apply to many other Antarctic ice shelves characterized by rift-tip alignment and spatial stiffness gradients. 
The Larsen $\mathrm{C}$ ice shelf appears to be in a stable configuration, with cyclical calving and regrowth, and little evidence of flow changes over the past $\sim 560$ years. Unlike the ice shelves further north on the Antarctic Peninsula, we see no evidence of climate-related retreat at this time.

\section{ACKNOWLEDGEMENTS}

N.F.G. acknowledges support from the US-UK Fulbright Commission as a Fulbright Distinguished Scholar, and also support from a CIRES (Cooperative Institute for Research in Environmental Sciences) Fellowship in Boulder, Colorado. We acknowledge constructive reviews from two anonymous referees.

\section{REFERENCES}

Bamber, J.L. and C.R. Bentley. 1994. A comparison of satellitealtimetry and ice-thickness measurements of the Ross Ice Shelf, Antarctica. Ann. Glaciol., 20, 357-364.

Bassis, J.N., R. Coleman, H.A. Fricker and J.B. Minster. 2005. Episodic propagation of a rift on the Amery Ice Shelf, East Antarctica. Geophys. Res. Lett., 32(6), L06502. (10.1029/ 2004GL022048.)

Bassis, J.N. and 7 others. 2007. Seismicity and deformation associated with ice-shelf rift propagation. J. Glaciol., 53(183), 523-536.

Bassis, J.N., H.A. Fricker, R. Coleman and J.-B. Minster. 2008. An investigation into the forces that drive ice-shelf rift propagation on the Amery Ice Shelf, East Antarctica. J. Glaciol., 54(184), $17-27$.

Bentley, C.R., J.W. Clough, K.C. Jezek and S. Shabtaie. 1979. Icethickness patterns and the dynamics of the Ross Ice Shelf, Antarctica. J. Glaciol., 24(90), 287-294.

Bindschadler, R. and W. Seider. 1998. Declassified intelligence satellite photography (DISP) coverage of Antarctica. NASA Tech. Mem. 1998-206879.

Bindschadler, R. and P. Vornberger. 1998. Changes in the West Antarctic ice sheet since 1963 from declassified satellite photography. Science, 279(5351), 689-692.

Bindschadler, R., T. Scambos, H. Rott, P. Skvarca and P. Vornberger. 2002. Ice dolines on Larsen Ice Shelf, Antarctica. Ann. Glaciol., 34, 283-290.

Bombosch, A. and A. Jenkins. 1995. Modeling the formation and deposition of frazil ice beneath Filchner-Ronne Ice Shelf. J. Geophys. Res., 100(C4), 6983-6992.

Braun, M., A. Humbert and A. Moll. 2008. Changes of Wilkins Ice Shelf over the past 15 years and inferences on its stability. Cryos. Discuss., 2(3), 341-382.

Casassa, G. and H.H. Brecher. 1993. Relief and decay of flow stripes on Byrd Glacier, Antarctica. Ann. Glaciol., 17, 255-261.

Casassa, G. and I.M. Whillans. 1994. Decay of surface topography on the Ross Ice Shelf, Antarctica. Ann. Glaciol., 20, 249-253.

Copland, L., D.R. Mueller and L. Weir. 2007. Rapid loss of the Ayles Ice Shelf, Ellesmere Island, Canada. Geophys. Res. Lett., 34(21), L21501. (10.1029/2007GL031809.)

Crabtree, R.D. and C.S.M. Doake. 1980. Flow lines on Antarctic ice shelves. Polar Rec., 20(124), 31-37.

De Angelis, H. and P. Skvarca. 2003. Glacier surge after ice shelf collapse. Science, 299(5612), 1560-1562.

Doake, C.S.M. and D.G. Vaughan. 1991. Rapid disintegration of the Wordie Ice Shelf in response to atmospheric warming. Nature, 350(6316), 328-330.

Domack, E. and 9 others. 2005. Stability of the Larsen B ice shelf on the Antarctic Peninsula during the Holocene epoch. Nature, 436(7051), 681-685.
Drewry, D.J., S.R. Jordan and E. Jankowski. 1982. Measured properties of the Antarctic ice sheet: surface configuration, ice thickness, volume and bedrock characteristics. Ann. Glaciol., 3, 83-91.

Dupont, T.K. and R.B. Alley. 2005. Assessment of the importance of ice-shelf buttressing to ice-sheet flow. Geophys. Res. Lett., 32(4), L04503. (10.1029/2004GL022024.)

Engelhardt, H. and J. Determann. 1987. Borehole evidence for a thick layer of basal ice in the central Ronne Ice Shelf. Nature, 327(6120), 318-319.

Evans, J. and C. ÓCofaigh. 2003. Supraglacial debris along the front of the Larsen-A Ice Shelf, Antarctic Peninsula. Antarct. Sci., 15(4), 503-506.

Fahnestock, M.A., T.A. Scambos, R.A. Bindschadler and G. Kvaran. 2000. A millennium of variable ice flow recorded by the Ross Ice Shelf, Antarctica. J. Glaciol., 46(155), 652-664.

Fricker, H.A., S. Popov, I. Allison and N. Young. 2001. Distribution of marine ice under the Amery Ice Shelf, East Antarctica. Geophys. Res. Lett., 28(11), 2241-2244.

Fricker, H.A., N.W. Young, I. Allison and R. Coleman. 2002. Iceberg calving from the Amery Ice Shelf, East Antarctica. Ann. Glaciol., 34, 241-246.

Fricker, H.A., N.W. Young, R. Coleman, J.N. Bassis and J.B. Minster. 2005. Multi-year monitoring of rift propagation on the Amery Ice Shelf, East Antarctica. Geophys. Res. Lett., 32(2), L02502. (10.1029/2004GL021036.)

Glasser, N.F. and T.A. Scambos. 2008. A structural glaciological analysis of the 2002 Larsen B ice-shelf collapse. J. Glaciol., 54(184), 3-16.

Hambrey, M.J. 1977. Foliation, minor folds and strain in glacier ice. Tectonophysics, 39(1-3), 397-416.

Hambrey, M.J. and J.A. Dowdeswell. 1994. Flow regime of the Lambert Glacier-Amery Ice Shelf system, Antarctica: structural evidence from Landsat imagery. Ann. Glaciol., 20, 401-406.

Hambrey, M.J. and N.F. Glasser. 2003. The role of folding and foliation development in the genesis of medial moraines: examples from Svalbard glaciers. J. Geol., 111(4), 471-485.

Hooke, R.LeB. and P.J. Hudleston. 1978. Origin of foliation in glaciers. J. Glaciol., 20(83), 285-299.

Jezek, K.C. 2002. RADARSAT-1 Antarctic Mapping Project: changedetection and surface velocity campaign. Ann. Glaciol., 34, 263-268.

Jezek, K.C. and H.X. Liu. 2005. Structure of southeastern Antarctic Peninsula ice shelves and ice tongues from synthetic aperture radar imagery. J. Glaciol., 51(174), 373-376.

Joughin, I. and D.R. MacAyeal. 2005. Calving of large tabular icebergs from ice shelf rift systems. Geophys. Res. Lett., 32(2), L02501. (10.1029/2004GL020978.)

Joughin, I. and D.G. Vaughan. 2004. Marine ice beneath the Filchner-Ronne Ice Shelf, Antarctica: a comparison of estimated thickness distributions. Ann. Glaciol., 39, 511-517.

Kim, K., K.C. Jezek and H. Liu. 2007. Orthorectified image mosaic of Antarctica from 1963 Argon satellite photography: image processing and glaciological applications. Int. J. Remote Sens., 28(23), 5357-5373.

Larour, E., E. Rignot and D. Aubry. 2004. Processes involved in the propagation of rifts near Hemmen Ice Rise, Ronne Ice Shelf, Antarctica. J. Glaciol., 50(170), 329-341.

Larour, E., E. Rignot, I. Joughin and D. Aubry. 2005. Rheology of the Ronne Ice Shelf, Antarctica, inferred from satellite radar interferometry data using an inverse control method. Geophys. Res. Lett., 32(5), L05503. (10.1029/2004GL021693.)

MacAyeal, D.R., T.A. Scambos, C.L. Hulbe and M.A. Fahnestock. 2003. Catastrophic ice-shelf break-up by an ice-shelf-fragmentcapsize mechanism. J. Glaciol., 49(164), 22-36.

Merry, C.J. and I.M. Whillans. 1993. Ice-flow features on Ice Stream B, Antarctica, revealed by SPOT HRV imagery. J. Glaciol., 39(133), 515-527. 
Nicholls, K.W., C.J. Pudsey and P. Morris. 2004. Summertime water masses off the northern Larsen C Ice Shelf. Geophys. Res. Lett., 31(9), L09309. (10.1029/2004GL019924.)

Pritchard, H.D. and D.G. Vaughan. 2007. Widespread acceleration of tidewater glaciers on the Antarctic Peninsula. J. Geophys. Res., 112(F3), F03S29. (10.1029/2006JF000597.)

Rack, W. and H. Rott. 2004. Pattern of retreat and disintegration of the Larsen B ice shelf, Antarctic Peninsula. Ann. Glaciol., 39, 505-510.

Reynolds, J.M. and M.J. Hambrey. 1988. The structural glaciology of George VI Ice Shelf, Antarctic Peninsula. Br. Antarct. Surv. Bull. 79, 79-95.

Rignot, E., G. Casassa, P. Gogineni, W. Krabill, A. Rivera and R. Thomas. 2004. Accelerated ice discharge from the Antarctic Peninsula following the collapse of Larsen B ice shelf. Geophys. Res. Lett., 31(18), L18401. (10.1029/2004GL020697.)

Rist, M.A. and 6 others. 1999. Experimental and theoretical fracture mechanics applied to Antarctic ice fracture and surface crevassing. J. Geophys. Res., 104(B2), 2973-2987.

Rist, M.A., P.R. Sammonds, H. Oerter and C.S.M. Doake. 2002. Fracture of Antarctic shelf ice. J. Geophys. Res., 107(B1), 2002. (10.1029/2000JB000058.)

Rommelaere, V. and D. R. MacAyeal. 1997. Large-scale rheology of the Ross Ice Shelf, Antarctica, computed by a control method. Ann. Glaciol., 24, 43-48.

Rott, H., P. Skvarca and T. Nagler. 1996. Rapid collapse of northern Larsen Ice Shelf, Antarctica. Science, 271(5250), 788-792.

Rott, H., W. Rack, T. Nagler and P. Skvarca. 1998. Climatically induced retreat and collapse of northern Larsen Ice Shelf, Antarctic Peninsula. Ann. Glaciol., 27, 86-92.

Scambos, T.A., C. Hulbe, M. Fahnestock and J. Bohlander. 2000. The link between climate warming and break-up of ice shelves in the Antarctic Peninsula. J. Glaciol., 46(154), 516-530.

Scambos, T., C. Hulbe and M. Fahnestock. 2003. Climate-induced ice shelf disintegration in the Antarctic Peninsula. In Domack, E.W., A. Burnett, A. Leventer, P. Conley, M. Kirby and R. Bindschadler, eds. Antarctic Peninsula climate variability: a historical and paleoenvironmental perspective. Washington, DC, American Geophysical Union, 79-92. (Antarctic Research Series 79.)

Scambos, T.A., J.A. Bohlander, C.A. Shuman and P. Skvarca. 2004. Glacier acceleration and thinning after ice shelf collapse in the
Larsen B embayment, Antarctica. Geophys. Res. Lett., 31(18), L18402. (10.1029/2004GL020670.)

Scambos, T.A., T.M. Haran, M.A. Fahnestock, T.H. Painter and J. Bohlander. 2007. MODIS-based Mosaic of Antarctica (MOA) data sets: continent-wide surface morphology and snow grain size. Remote Sens. Environ., 111(2-3), 242-257.

Shepherd, A., D. Wingham, T. Payne and P. Skvarca. 2003. Larsen ice shelf has progressively thinned. Science, 302(5646), 856-859.

Skvarca, P. 1993. Fast recession of the northern Larsen Ice Shelf monitored by space images. Ann. Glaciol., 17, 317-321.

Skvarca, P. 1994. Changes and surface features of the Larsen Ice Shelf, Antarctica, derived from Landsat and Kosmos mosaics. Ann. Glaciol., 20, 6-12.

Smith, J.A., M.J. Bentley, D.A. Hodgson and A.J. Cook. 2007. George VI Ice Shelf: past history, present behaviour and potential mechanisms for future collapse. Antarct. Sci., 19(1), 131-142.

Swithinbank, C., K. Brunk and J. Sievers. 1988. A glaciological map of Filchner-Ronne Ice Shelf, Antarctica. Ann. Glaciol., 11, 150-155.

Thomas, R.H., T.J.O. Sanderson and K.E. Rose. 1979. Effect of climatic warming on the West Antarctic ice sheet. Nature, 277(5695), 355-358.

Van den Broeke, M. 2005. Strong surface melting preceded collapse of Antarctic Peninsula ice shelf. Geophys. Res. Lett., 32(12), L12815. (10.1029/2005GL023247.)

Van der Veen, C.J. 1998. Fracture mechanics approach to penetration of bottom crevasses on glaciers. Cold Reg. Sci. Technol., 27(3), 213-223.

Vaughan, D.G. 1993. Relating the occurrence of crevasses to surface strain rates. J. Glaciol., 39(132), 255-266.

Vaughan, D.G. and C.S.M. Doake. 1996. Recent atmospheric warming and retreat of ice shelves on the Antarctic Peninsula. Nature, 379(6563), 328-331.

Vieli, A., A.J. Payne, Z. Du and A. Shepherd. 2006. Numerical modelling and data assimilation of the Larsen B ice shelf, Antarctic Peninsula. Philos. Trans. R. Soc. London, Ser. A, 364(1844), 1815-1839.

Weiss, J. 2004. Subcritical crack propagation as a mechanism of crevasse formation and iceberg calving. J. Glaciol., 50(168), 109-115. 